\title{
Survivorship and Causes of Mortality for Livestock-Guarding Dogs on Namibian Rangeland
}

\author{
Laurie L. Marker, ${ }^{1}$ Amy J. Dickman, ${ }^{2}$ and David W. Macdonald ${ }^{3}$ \\ Authors are ${ }^{1}$ Director and ${ }^{2}$ Senior Research Assistant, Cheetah Conservation Fund, PO Box 1755, Otjiwarongo, Namibia; and \\ ${ }^{3}$ Professor and Director, Wildlife Conservation Research Unit, 30 South Parks Road, Oxford, United Kingdom OX1 3PS.
}

\begin{abstract}
This paper reports upon the survivorship of 143 livestock-guarding dogs placed on Namibian rangeland between January 1994 and January 2002 as part of a study of techniques that could be used to reduce stock losses on commercial ranches and communal farms. During the study period, 61 (42.7\%) of the dogs placed were removed from working situations. Deaths accounted for $49(80.3 \%)$ of removals, while the remaining $12(19.7 \%)$ were transfers out of the program. Causes of death varied by both farm type and age group. The most common cause of death for working dogs, especially young ones, was accidental, which accounted for 22 reported deaths, while culling of the dog by the owner was the reason for 12 working dog deaths, all of which occurred on commercial ranches. The mean survival time as a working dog was estimated as $4.16( \pm 0.40)$ years for males, $4.65( \pm 0.45)$ years for females, and $4.31( \pm 0.31)$ years for all dogs placed. Survival distributions differed slightly $(P=0.049)$ between farm types, with adult mortality less common on communal farms than on commercial ranches. There was no significant difference $(P=0.612)$ between the sexes regarding survival distributions. With good care of the dogs and sufficient information provided to farmers, guarding dogs can act as an effective and economically beneficial method of livestock protection, with implications for range management both in Namibia and elsewhere.
\end{abstract}

\section{Resumen}

Este artículo reporta la superviviencia de 143 perros guardianes colocados en pastizales de Namibia entre Enero de 1994 y Enero de 2002, como parte de un estudio de técnicas que pudieran ser usadas para reducir las perdidas de ganado en ranchos comerciales y granjas comunales. Durante el periodo de estudio, 61 (42.7\%) de los perros fueron removidos de las estaciones de trabajo. Del total de los perros removidos, 49 (80.3\%) fueron por causa de muerte, mientras que los 12 restantes (19.7\%) fueron transferidos fuera del programa. Las causas de muerte variaron por tipo de granja y grupo de edad. La causa más común de muerte para perros trabajando, especialmente los jóvenes, fue accidental, la cual contribuyó con 22 de las muertes reportadas; otras 12 fueron porque el dueño desechó el perro, todas ellas ocurrieron en los ranchos comerciales. El tiempo promedio de superviviencia de un perro trabajando se estimó en $4.16( \pm 0.40)$ años para los machos y $4.65( \pm 0.45)$ para las hembras y de 4.31 $( \pm 0.31)$ para todo el grupo de perros. La distribución de superviviencia difirió ligeramente $(P=0.049)$ entre tipos de granja, la mortalidad de adultos fue menos común en las granjas comunales que en las comerciales. No hubo diferencias significativas $(P=0.612)$ entre sexos del animal con respecto a las distribución de superviviencia. Con un buen cuidado de los perros e información suficiente suministrada a los granjeros, los perros guardianes pueden actuar como un método efectivo y econonómicamente benéfico de protección del ganado, con implicaciones de manejo de pastizales tanto para Namibia como para cualquier otro lugar.

Key Words: Anatolian Shepherd, cheetah, livestock loss, Namibia

\section{INTRODUCTION}

Worldwide, livestock loss is an issue of pressing importance for rangeland managers because such losses can have a substantial economic impact (Yom-Tov et al. 1995; Butler 2000). This is particularly true in developing countries, especially on subsistence farms, where even a relatively small level of livestock loss can have devastating financial implications for the farmer concerned (Oli et al. 1994; Mishra 1997). Moreover, in many

Research was funded in part by the African Wildlife Foundation, the Cheetah Conservation Fund-USA, the Cincinnati Zoo, Earthwatch Institute, the Weeden Foundation, the WILD Foundation, and the World Wildlife Fund South Africa Green Trust.

Correspondence: Laurie Marker, Cheetah Conservation Fund, PO Box 1755, Otjiwarongo, Namibia. Email: cheetah@iway.na

Manuscript received 27 September 2003; manuscript accepted 19 February 2005. farming communities, livestock has value that transcends its economic worth, due to additional considerations such as the higher social status of farmers with large herds or the maintenance of specific breeding lines. Therefore, developing techniques that effectively reduce levels of stock loss are an important component of successful rangeland management.

Large percentages of stock losses are frequently attributed to predators (Bruggers and Zaccagnini 1994; Mishra 1997), although several studies have shown that predators are often blamed for losses caused by other factors such as stock theft, disease, and accidental death (Mishra 1997; Rasmussen 1999). Historically, this situation has resulted in widespread antipathy towards predators by livestock producers, with extensive eradication of carnivores in many ranching areas (Rasmussen 1999; Allen and Sparkes 2001). This strategy has resulted in the extirpation of carnivores from much of their former ranges, as has been seen with the wolf (Canis lupus) in Europe, the 
mountain lion (Felis concolor) in the United States, and predators such as the African wild dog (Lycaon pictus), spotted hyena (Crocuta crocuta), and lion (Panthera leo) in Africa (Woodroffe 2001; Mazzolli et al. 2002).

Today, however, many of the carnivores responsible for depredation are themselves threatened, as is the case with the cheetah (Acinonyx jubatus) on Namibian rangelands (Marker et al. 2003), and solutions to stock loss must be sought that do not rely upon elimination of predators from the system. Furthermore, many of the control techniques traditionally used to reduce depredation have had serious ecological consequences, e.g., poisoning efforts resulting in secondary poisoning of nontarget species (Yom-Tov et al. 1995) and widespread trapping resulting in the deaths of many animals apart from the those actually causing conflict (Treves and Karanth 2003). Aside from welfare considerations, the indiscriminate use of such lethal control measures, especially poisoning, can have damaging long-term effects on the ranchland ecosystem. Moreover, carnivores are a vital part of a healthy ecosystem, playing important roles such as the regulation of prey and mesopredator populations, and their removal can have substantial negative effects on the system (Berger 1999; Linnell and Strand 2000; Terborgh et al. 2002). It is the responsibility of ranchers to minimize the negative ecological impacts of their activities, and as such, the development of effective methods of reducing stock loss that do not rely on lethal techniques or predator exclusion has substantial benefits both for ranchers and for conservation.

The use of guarding dogs is a potentially useful method of reducing livestock losses, has little ecological impact, and allows predators to remain present in the system (Landry 2001). Research conducted on Namibian rangeland has indicated that the placement of Anatolian Shepherd guarding dogs can significantly reduce livestock depredation on both communal farms and commercial ranches (Marker et al. 2005). It is important, however, that guarding dogs are both efficient and cost-effective. Farmers will only use an economically viable technique, and for guarding dogs, the ability to deter predators and the longevity of the dogs are key factors in determining success (Green et al. 1984). Dogs working on rangelands tend to be relatively short-lived, mainly because of accidents or culling due to inappropriate behavior (Lorenz et al. 1986), and maximizing the lifespan of a working guardian is vital in order to reap the most economic benefit from investing in guarding dogs. We evaluated the survivorship of guarding dogs placed on Namibian rangeland, and investigated the causes of death and removal, so that factors leading to the removal of these guardians could be better understood and prevented.

\section{METHODS}

The study was conducted on both communal and commercial rangeland in Namibia. The commercial ranches supported abundant populations of free-ranging game, averaged 8995 $( \pm 443.9)$ ha in size and were primarily bush-encroached thornbush savanna and grassland (Joubert and Mostert 1975). The arid environment and the encroached bush meant that farmers had to use extensive farming methods, usually allowing their stock to range over large areas in the day before corralling them at night.

Communal farms, by contrast, supported little wildlife and averaged 20 homesteads and 100 people per village. Each homestead in a village had its own herds of stock, and each owner had his own type of management system, although the majority of communal farmers used an open grazing system with no fences except a livestock kraal near the homestead.

The Cheetah Conservation Fund began a livestock-guarding dog program in 1994, and 143 dogs have been placed on Namibian farms and ranches since its inception. The program was initiated with the import of 10 Anatolian Shepherds from the Birinci line in the United States, and breeding commenced within Namibia in 1994, with 2 additional males imported later for breeding purposes. All dogs bred in Namibia were kept with their dam for 6-8 weeks and housed in close proximity to livestock in order to familiarize them with stock before placement.

Farmers and ranchers who were interested in obtaining a guarding dog were asked to complete a potential owner's questionnaire, with the aim of placing dogs on rangeland where stock losses to predators occurred. Dogs were monitored throughout their lives, following Coppinger and Coppinger (1980), with periodic assessments of the protectiveness and attentiveness shown by the dog towards stock and the trustworthiness of the dog around stock. In addition, we quantified the care given to the dog by the farmer or rancher, and satisfaction of the farmer or rancher with the dog. All these factors were assessed through interviews with owners and visits to the ranches where the dogs were working. The traits were scored on a scale from $0-1$, with 0 indicating no evidence of that trait at all, and 1 indicating the maximum possible score attainable. Detailed methodology of livestock-guarding dog placement and monitoring can be found in Marker et al. (2005).

No charge was made for the dogs, and neutering and all vaccinations for the first 6 weeks were provided free of charge on both commercial ranches and communal farms. All followup vaccinations were also provided free of charge for dogs placed on communal farms. Placement of dogs on commercial ranches began in January 1994, and the first guarding dogs were placed on communal farms in February 1997.

When guarding dogs were removed from a working situation, all possible attempts were made to determine the reason for the removal, and, in the case of death, the cause of death was ascertained. Accidental deaths included drowning, snakebite, and being killed by baboons or hit by vehicles. Calculations of survivorship referred to the end of a dog's working life, regardless of whether the dog was removed to become a pet or breeding animal, or actually died. Survivorship analyses were restricted to dogs that had been placed as working guardians, and excluded other cases such as infant mortality.

Statistical analyses were performed using SPSS version 10.0 software (SPSS Inc., Chicago, IL). Normality of variables was tested using the Kolmogorov-Smirnov and Shapiro-Wilk tests; in cases where there was significant deviation from normality, nonparametric tests were used. Paired means analyses were conducted using the Mann-Whitney $U$ procedure, and the independent samples $t$-test was used to compare the means of normally distributed data, using Levene's test to determine the equality of variances. Departures from expected ratios were 
Table 1. Number of livestock guarding dogs placed, removed (through either deaths or transfers), and still working on Namibian farms as of December 2001, separated by sex and type of farm on which dogs were placed. Numbers in parentheses indicate the percentage of dogs placed that have experienced that fate.

\begin{tabular}{|c|c|c|c|c|c|c|c|}
\hline & \multicolumn{3}{|c|}{ Commercial ranches } & \multicolumn{3}{|c|}{ Communal farms } & \multirow[b]{2}{*}{ Overall total } \\
\hline & Male & Female & Total & Male & Female & Total & \\
\hline No. placed & 49 & 57 & 106 & 27 & 10 & 37 & 143 \\
\hline No. died (\% of those placed) & $25(51.2)$ & $19(33.3)$ & $44(41.5)$ & $4(14.8)$ & $1(10.0)$ & $5(13.5)$ & $49(34.3)$ \\
\hline No. transferred out (\% of those placed) & $5(10.2)$ & $6(10.5)$ & $11(10.4)$ & $1(3.7)$ & $0(0.0)$ & $1(2.7)$ & $12(8.4)$ \\
\hline Total no. removals (\% of those placed) & $30(61.2)$ & $25(43.9)$ & $55(51.9)$ & $5(18.5)$ & $1(10.0)$ & $6(16.2)$ & $61(42.7)$ \\
\hline $\begin{array}{l}\text { No. working at end of study (\% of } \\
\text { those placed) }\end{array}$ & $19(38.8)$ & $32(56.1)$ & $51(48.1)$ & 22 (81.5) & $9(90.0)$ & 31 (83.8) & $82(57.3)$ \\
\hline
\end{tabular}

analyzed using chi-square tests. Relationships between variables were investigated using partial correlations if there was known to be a confounding variable, such as age of the dog. Breslow's test (generalized Wilcoxon's) was used to examine the equality of survival distributions, and all tests were 2-tailed unless otherwise stated.

\section{RESULTS}

During the 8-year study period, from January 1994 to December 2001, 143 guarding dogs were placed on ranches or farms as working guardians. The breakdown of the placed dogs, separated by sex and farm or ranch type, is given in Table 1.

\section{Mortality}

Over one-third of the dogs $(n=49)$ that entered the program were reported to have died while they were still actively working as guardians (Table 1). The sex ratio of reported deaths did not differ significantly from the sex ratio of dogs placed $\left(\chi^{2}=0.728, \mathrm{df}=1, P=0.323\right)$.

Age at death was known for $46(93.9 \%)$ of the dogs that died as working dogs, and ranged from 2.5 months to 5.8 years (Table 2). Over one-third of the deaths $(n=18,39.1 \%)$ involved dogs that were under a year old, while a further 14 $(30.4 \%)$ of the deaths occurred in the second year of life.
Overall, there was no significant difference between the sexes regarding age at death for working dogs (MWU: $z=-1.51$, $P=0.132$ ), or between those dogs placed on commercial ranches and those on communal farms (MW $U: z=-1.41$, $P=0.158)$.

Almost $90 \%$ of reported deaths $(89.8 \%, n=44)$ occurred on commercial ranches, but this bias would be expected as placements began 3 years earlier on commercial ranches than on communal farms. However, even when analyses were restricted to dogs placed since 1997, when placements were occurring on both farm types, slightly more deaths occurred on commercial ranches than would be expected from the ratio of placements $\left(\chi^{2}=3.99\right.$, $\left.\mathrm{df}=1, P=0.046\right)$.

Cause of death was known in 42 of the 49 cases where working dogs were reported to have died. Accidents were the single most common cause of working dog deaths $(n=22)$, followed by culling by the owner $(n=12)$, which presumably occurred because the farmer or rancher was dissatisfied with behavioral traits of the dog, such as a tendency to chase or harass stock. Six dogs were killed by neighboring ranchers, and disease and poisoning accounted for 1 death each. Causes of death for working dogs differed significantly between commercial ranches and communal farms $\left(\chi^{2}=13.3, \mathrm{df}=5, P=0.021\right.$; Fig. 1$)$. All incidents of culling, whether by the dog's owner or a neighboring rancher, occurred on commercial ranches, while all cases of disease and poisoning occurred on communal farms. There was

Table 2. Descriptive statistics for age at death, time in program before removal (for dogs that were removed, either due to death or transfer, during the study period), and time in program for dogs still working at the end of the study period, in December 2001. SE indicates the standard error.

\begin{tabular}{|c|c|c|c|c|c|c|c|c|c|}
\hline & \multicolumn{3}{|c|}{ Age at death $(y)$} & \multicolumn{3}{|c|}{ Time in program before removal $(\mathrm{y})$} & \multicolumn{3}{|c|}{$\begin{array}{c}\text { Time in program for dogs still } \\
\text { working at end of study period }(y)\end{array}$} \\
\hline & $n$ & Mean & SE & $n$ & Mean & SE & $n$ & Mean & SE \\
\hline Commercial ranches-male dogs & 23 & 2.22 & 0.35 & 27 & 1.98 & 0.30 & 19 & 3.81 & 0.54 \\
\hline Commercial ranches-female dogs & 18 & 1.28 & 0.19 & 24 & 1.13 & 0.17 & 32 & 3.22 & 0.40 \\
\hline Communal farms-male dogs & 4 & 1.07 & 0.30 & 5 & 1.03 & 0.26 & 22 & 2.02 & 0.27 \\
\hline Communal farms_female dogs & 1 & 0.27 & 0.00 & 1 & 0.13 & 0.00 & 9 & 1.80 & 0.40 \\
\hline Male dogs overall & 27 & 2.05 & 0.30 & 32 & 1.09 & 0.17 & 41 & 2.85 & 0.32 \\
\hline Female dogs overall & 19 & 1.22 & 0.18 & 25 & 1.83 & 0.26 & 41 & 2.91 & 0.34 \\
\hline Commercial ranches overall & 41 & 1.81 & 0.22 & 51 & 1.58 & 0.19 & 51 & 3.44 & 0.32 \\
\hline Communal farms overall & 5 & 0.91 & 0.28 & 6 & 0.88 & 0.26 & 31 & 1.96 & 0.22 \\
\hline All dogs & 46 & 1.71 & 0.20 & 57 & 1.51 & 0.17 & 82 & 2.88 & 0.23 \\
\hline
\end{tabular}




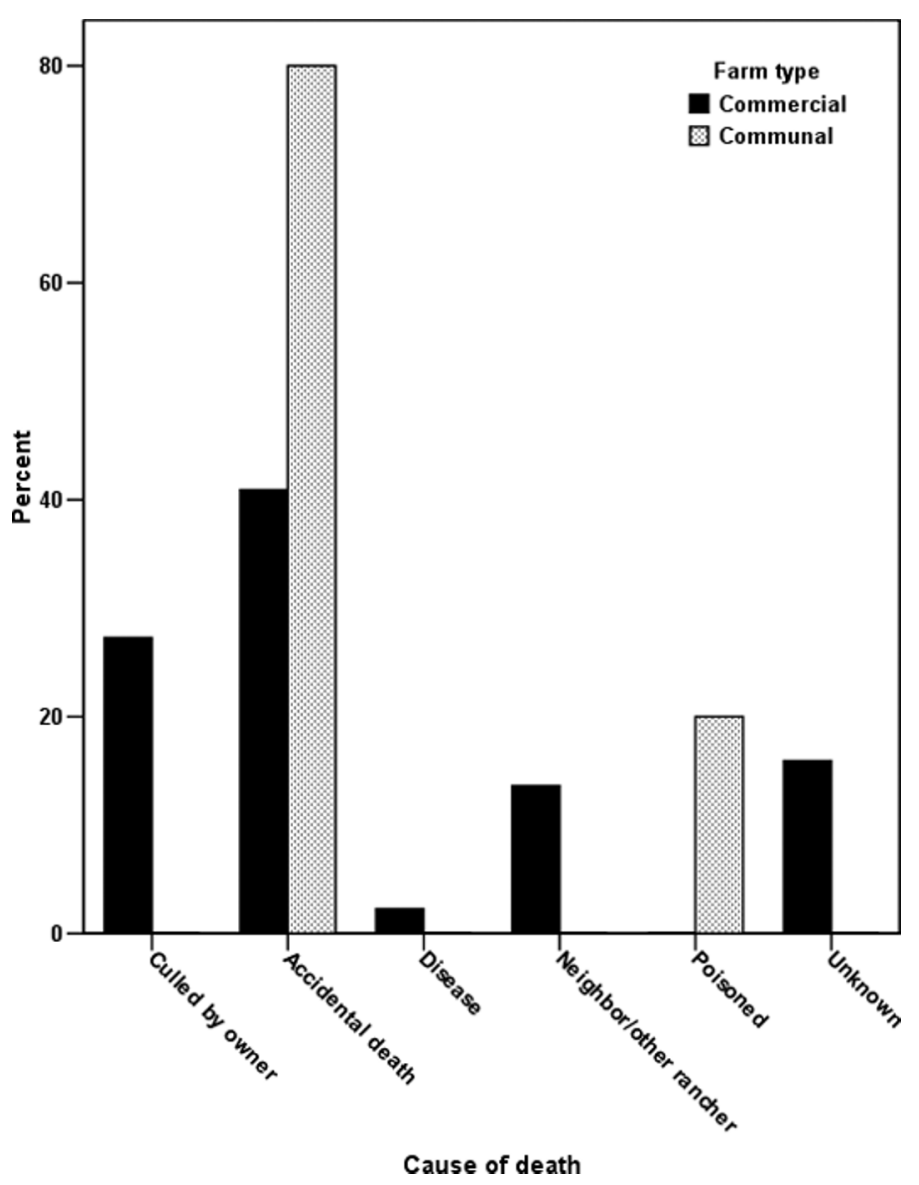

Figure 1. Reported causes of death for livestock-guarding dogs that died while still active in Namibia as working dogs $(n=49)$, separated by whether they died while working on a commercial ranch $(n=44)$ or on a communal farm $(n=5)$.

no significant difference between farm types in terms of accidental deaths $\left(\chi^{2}=6.83, \mathrm{df}=1, P=0.409\right)$.

Figure 2 shows the breakdown of causes of death for working dogs by age group. Cause of death varied significantly from the expected ratio for both puppies $\left(\chi^{2}=10.00, \mathrm{df}=1\right.$, $P=0.019)$ and juvenile $\operatorname{dogs}\left(\chi^{2}=8.29, \mathrm{df}=3, P=0.040\right)$, but not for adults $\left(\chi^{2}=2.43, \mathrm{df}=4, P=0.657\right)$. Accidents were the most common cause of death in young dogs, accounting for $10(55.6 \%)$ of the reported deaths for dogs under a year old, and for $8(57.1 \%)$ of the juvenile deaths. Four $(28.6 \%)$ of the reported adult dog deaths were due to accidents, equal to the number that were culled by their owners.

\section{Overall Survivorship of Working Dogs}

In addition to the 49 dogs that died as working dogs, 12 dogs were transferred out of the working population and were either adopted as pets or used for breeding purposes. Combining the mortality data with these removals indicated that almost half of the 143 dogs placed as working dogs were eliminated from the program (Table 1). Just over $80 \%(n=49)$ of removals were due to death, while $19.7 \%(n=12)$ of removals were due to transfers.

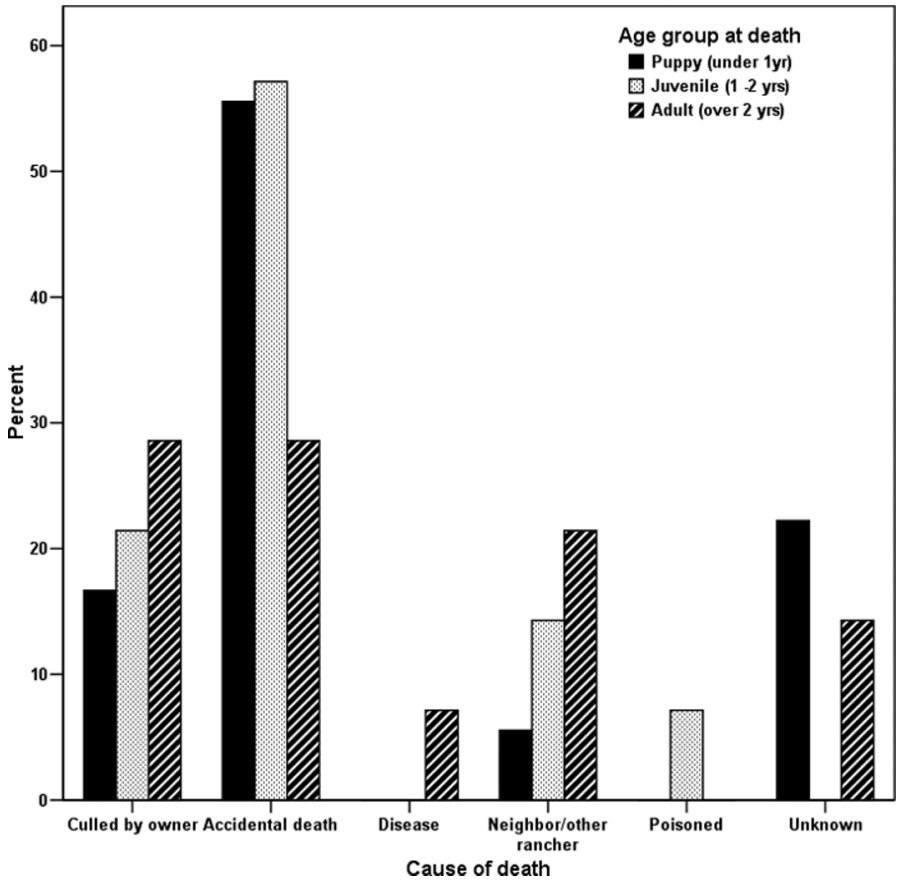

Figure 2. Reported causes of death for dogs that died while still active as guardians on Namibian farms, separated by age class. Age classes were defined as follows: puppy ( 1 year old, $n=18$ deaths), juvenile (12 years old, $n=14$ deaths) and adult ( $>2$ years old, $n=14$ deaths).

Time in the program before removal could be calculated for 57 removed dogs, and ranged from 3 weeks to 5.6 years (Table 2). There was no significant difference between the sexes in time before removal ( $M W U: z=-1.77, P=0.077$ ), nor was there a difference between dogs placed on different farm types ( $M W U: z=-1.18, P=0.237$ ).

Just over half the dogs placed were still working by the end of the study period (Table 2), and had spent between 3 days and 7.6 years working as livestock guardians. Again, neither sex $(t=0.121, \mathrm{df}=80, P=0.904)$ nor farm type (controlling for date of placement: $t=1.391, \mathrm{df}=68, P=0.169$ ) significantly affected the time spent working by the end of the study period.

These figures are skewed by the fact that at the end of the study period many dogs had been in the program for only a short time, and may spend many more years as effective livestock guardians. The life table (Table 3), which represents dogs that were transferred out of the population in the same way as those that died, reveals the probable 'survival' as working dogs. Overall, the dogs had a $43 \%$ chance of making it to the fifth year of working life, with dogs placed on communal farms almost twice as likely to reach this stage as those on commercial ranches. A Kaplan-Meier analysis estimated mean survival times in the program of $4.16( \pm 0.40)$ years for males and $4.65( \pm 0.45)$ years for females, with an overall mean for all dogs placed of $4.31( \pm 0.31)$ years. Males and females had similar survival distributions, both on commercial ranches (Breslow's test $=0.04, \mathrm{df}=1, P=0.842$ ), communal farms (Breslow's test $=0.00, \mathrm{df}=1, P=0.967$ ) and overall (Breslow's test $=0.26, \mathrm{df}=1, P=0.612$ ). 
Table 3. Life table for dogs placed as livestock guardians on Namibian rangeland, using 1-year intervals of time spent in the program. 'Termination' referred to a working dog being removed from the population for any reason, such as death or transfer into a pet or breeding situation, and was not restricted to actual mortality. The cumulative proportion surviving for an interval was the product of all proportions surviving up to and including that time interval. SE represents standard error.

\begin{tabular}{|c|c|c|c|c|c|c|c|c|c|}
\hline \multirow[b]{2}{*}{$\begin{array}{l}\text { Time in } \\
\text { program }(y)\end{array}$} & \multicolumn{3}{|c|}{ All dogs placed $(n=143)$} & \multicolumn{3}{|c|}{$\begin{array}{l}\text { Dogs placed on commercial } \\
\text { ranches }(n=106)\end{array}$} & \multicolumn{3}{|c|}{$\begin{array}{l}\text { Dogs placed on communal } \\
\text { farms }(n=37)\end{array}$} \\
\hline & $\begin{array}{l}\text { Proportion } \\
\text { terminating }\end{array}$ & $\begin{array}{l}\text { Proportion } \\
\text { surviving }\end{array}$ & $\begin{array}{l}\text { Cumulative proportion } \\
\text { surviving at end (SE) }\end{array}$ & $\begin{array}{l}\text { Proportion } \\
\text { terminating }\end{array}$ & $\begin{array}{l}\text { Proportion } \\
\text { surviving }\end{array}$ & $\begin{array}{l}\text { Cumulative proportion } \\
\text { surviving at end (SE) }\end{array}$ & $\begin{array}{l}\text { Proportion } \\
\text { terminating }\end{array}$ & $\begin{array}{l}\text { Proportion } \\
\text { surviving }\end{array}$ & $\begin{array}{l}\text { Cumulative proportion } \\
\text { surviving at end (SE) }\end{array}$ \\
\hline $0-1$ & 0.18 & 0.82 & $0.82(0.03)$ & 0.21 & 0.79 & $0.79(0.04)$ & 0.10 & 0.90 & $0.90(0.05)$ \\
\hline $1-2$ & 0.19 & 0.81 & $0.66(0.04)$ & 0.21 & 0.80 & $0.63(0.05)$ & 0.15 & 0.85 & $0.77(0.08)$ \\
\hline $2-3$ & 0.18 & 0.82 & $0.55(0.04)$ & 0.22 & 0.78 & $0.49(0.05)$ & 0.00 & 1.00 & $0.77(0.08)$ \\
\hline $3-4$ & 0.06 & 0.94 & $0.51(0.05)$ & 0.07 & 0.93 & $0.46(0.06)$ & 0.00 & 1.00 & $0.77(0.08)$ \\
\hline $4-5$ & 0.16 & 0.84 & $0.43(0.06)$ & 0.17 & 0.83 & $0.38(0.06)$ & 0.00 & 1.00 & $0.77(0.08)$ \\
\hline $5-6$ & 0.08 & 0.92 & $0.39(0.07)$ & 0.08 & 0.91 & $0.35(0.06)$ & - & - & - \\
\hline $6-7$ & 0.00 & 1.00 & $0.39(0.07)$ & 0.00 & 1.00 & $0.35(0.06)$ & - & - & - \\
\hline $7-8$ & 0.00 & 1.00 & $0.39(0.07)$ & 0.00 & 1.00 & $0.35(0.06)$ & - & - & - \\
\hline
\end{tabular}

Estimated survival time was $3.98( \pm 0.34)$ years for dogs placed on commercial ranches and $4.02( \pm 0.31)$ years on communal farms. There was a slight inequality of survival distributions between dogs placed on different farm types (Breslow's test $=3.86, \mathrm{df}=1, P=0.049$ ), with dogs on communal farms showing lower levels of adult mortality than their counterparts on commercial land (Fig. 3).

\section{Factors Affecting the Removal of Dogs}

Partial correlations, accounting for the age of the dog, revealed that the time spent in the program as a working guardian was significantly linked to the attentiveness of the dog $(n=89$; $r=0.27, P=0.010)$, as well as its trustworthiness $(r=0.34$, $P=0.001)$, and the satisfaction of the farmer $(r=0.25$, $P=0.016)$. Time in the program showed some positive relationship with protectiveness, although the trend was not statistically significant $(r=0.19, n=89, P=0.079)$. Evaluations of dogs that were eventually removed showed that they were less attentive, protective, and trustworthy than dogs that were not removed, that they were given less care, and the farmer was less satisfied (Table 4). The only differences that proved to be statistically significant, however, were the differences in trustworthiness ( $M W U: z=2.02, P=0.043)$ and farmer satisfaction ( $M W U: z=-2.52, P=0.012$ ).

Dogs were removed from commercial ranches significantly more often than expected, based on the proportion placed on commercial ranches $\left(\chi^{2}=8.72, \mathrm{df}=1, P=0.003\right)$. The sex ratio of the removed dogs, however, did not differ significantly from that of the placed population $\left(\chi^{2}=0.45, \mathrm{df}=1\right.$, $P=0.503)$.

\section{DISCUSSION}

Although the mortality rate in this study is lower than the $48 \%$ reported for guarding dogs used in the United States (Lorenz et al. 1986), it is still high, with over one-third of the dogs placed dying during the study period, and almost half of the working dogs being removed. Accidents and culling were both important causes of death, with factors such as disease being virtually insignificant. These mortality factors are very different from those seen with domestic dogs but similar to the American population of guarding dogs (Lorenz et al. 1986). Accidents were found to be an important mortality factor, especially for young dogs, which was to be expected given the dangerous circumstances that working dogs are exposed to in Namibia. Attentiveness of the dog was found to be an important factor influencing removals in a US study, as inattentive dogs were more likely to be lost or killed (Lorenz et al. 1986). Although there was some indication of the same effect here, as attentiveness was positively related to time spent working as a guardian, there was no overall significant difference in attentiveness between dogs that were removed during the program and those that were not.

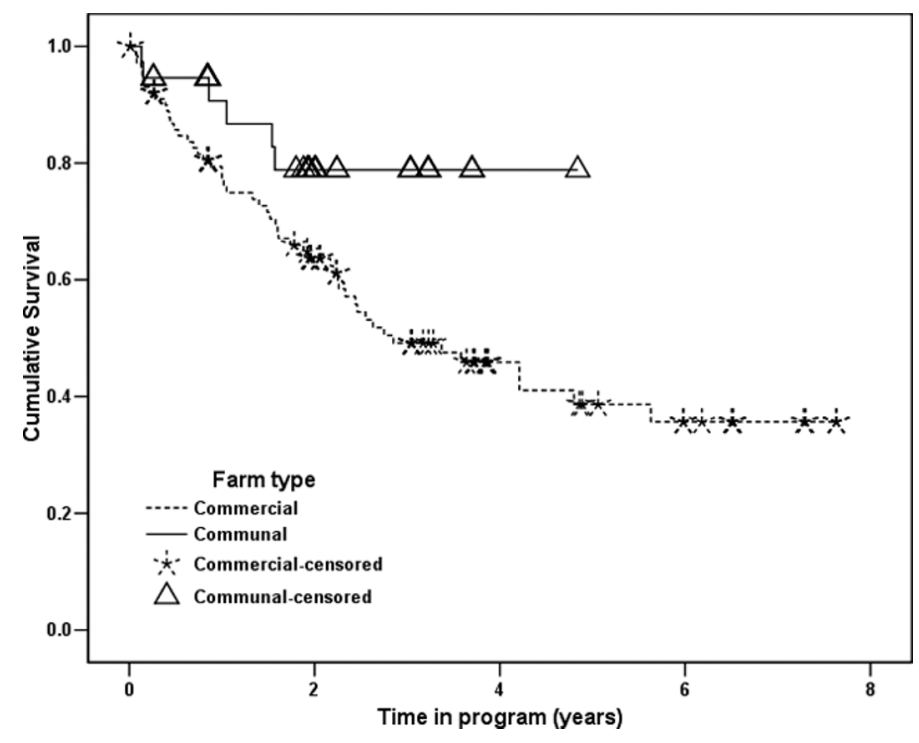

Figure 3. Kaplan-Meier survival function for livestock-guarding dogs placed on commercial ranches and communal farms in Namibia. Censored cases (i.e., those that were placed but were not removed during the study period) for each farm type are shown on the relevant survival. 
Table 4. Scores for livestock-guarding dogs that were placed on Namibian farms and removed from the program (i.e., died or were transferred), and for those dogs that were not removed. Scores for the 2 groups of dogs were compared using a Mann-Whitney U test. Traits examined were the attentiveness and protectiveness of the dog towards the stock, trustworthiness around the stock, care given to the dog by the farmer, and satisfaction of the farmer with the dog. Scores were evaluated on a scale from $0-1$, with 0 indicating no evidence of that factor, and 1 denoting the maximum attainable score. SE indicates standard error.

\begin{tabular}{|c|c|c|c|c|c|c|}
\hline & \multicolumn{2}{|c|}{$\begin{array}{c}\text { Dogs removed from } \\
\text { program }(n=57)\end{array}$} & \multicolumn{2}{|c|}{$\begin{array}{c}\text { Dogs not removed } \\
\text { from program }(n=82)\end{array}$} & \multicolumn{2}{|c|}{$\begin{array}{l}\text { Test between removed } \\
\text { and nonremoved dogs }\end{array}$} \\
\hline & Mean & SE & Mean & SE & $z$ & $P$ \\
\hline Attentiveness & 0.82 & 0.03 & 0.87 & 0.02 & -1.00 & 0.316 \\
\hline Protectiveness & 0.64 & 0.05 & 0.73 & 0.03 & -1.53 & 0.126 \\
\hline Trustworthiness & 0.37 & 0.05 & 0.51 & 0.04 & -2.02 & 0.043 \\
\hline Care given to dog & 0.80 & 0.03 & 0.85 & 0.02 & -1.71 & 0.087 \\
\hline Farmer satisfaction & 0.70 & 0.05 & 0.82 & 0.03 & -2.52 & 0.012 \\
\hline
\end{tabular}

As well as attentiveness, the working lifespan of a guarding dog on Namibian rangelands was linked to its trustworthiness and the farmer or rancher's overall satisfaction with the dog. Dogs that exhibited undesirable traits such as chasing, biting, or harassing stock were considered untrustworthy (Marker et al. 2005), and as such were more likely to be culled. The significance of culling as a cause of mortality was similar to the situation reported on American ranches, where culling due to inappropriate behavior accounted for a third of working dog deaths (Lorenz et al. 1986).

Culling accounted for almost a quarter of working dog deaths in this study, slightly lower than the $33 \%$ reported by Lorenz et al. (1986), or the $27 \%$ by Green and Woodruff (1990). For both puppies and juvenile dogs, around a fifth of deaths were due to culling by the owner. Guarding dogs, especially subadults, often exhibit unwanted behavioral traits at some stage in their working lives, and this has been reported both on the Namibian farmlands and for guarding dogs placed elsewhere (Coppinger and Coppinger 1980; Lorenz and Coppinger 1986; Marker et al. 2005). The high level of culling may reflect farmers' frustration with such problems, and a lack of interest or capacity to invest time and energy to remedy the problem. Our previous research in Namibia indicated, however, that the majority of problems could be solved with suitable corrective training (Marker et al. 2005), and this fact, combined with the evidence that even dogs that exhibit some unwanted behaviors are usually very effective in reducing losses, should discourage farmers from readily culling a problematic dog.

Moreover, although guarding dogs may show some precursors of effective guardianship while they are young, the full range of operative behavior only manifests itself with adulthood (Lorenz and Coppinger 1986; Sims and Dawydiak 1990). Previous studies have shown that annual costs for guarding dogs are highest in the first and second years of working life, due to factors such as immunizations, health certificates, transport costs, neutering, and the essentially ineffective time while the guardian is a small puppy, but annual cost declines throughout a dog's working lifespan (Lorenz et al. 1986). The first-year costs for dogs placed in Namibia were relatively low, as the Cheetah Conservation Fund bore the placement costs such as immunization, transport, and neutering. However, farmers should still be encouraged to work through problems encountered with young dogs, rather than culling them, as such problems are usually correctable (Marker et al. 2005), and a longer lifespan is likely to result in greater economic benefits to the rancher concerned.

Culling by neighbors accounted for deaths on several ranches, and this culling has been reported as a problem by previous authors (Green et al. 1984). Neighboring farmers may not realize that the dog is meant to be with the stock, and shoot it to prevent it from causing problems. Dogs may also cause problems by being overly protective and becoming aggressive towards any neighbor's stock that they encounter, by chasing game onto a neighbor's ranch, or by visiting a neighbor's ranch when one of their domestic dogs is in season.

Survival distributions differed slightly by ranch type, with lower adult mortality evident on communal farms. This pattern reflected the different causes of mortality: accidents, which mainly affected young dogs, were the predominant cause of death on communal farms, while the culling of adult dogs influenced the survival distribution on commercial ranches. This result was the opposite of that described by Lorenz et al. (1986); they found that survival distributions became very similar after 30 months of age, regardless of the ranch management system used. Overall, we found that an Anatolian Shepherd livestock-guarding dog placed in Namibia was likely to survive as a guardian for just over 4 years, with ranch type but not sex influencing the working lifespan. The dogs had a $43 \%$ chance of reaching 5 years of working age, which was better than in the United States, where $50 \%$ of the dogs died by the time they were 18 months old if they were placed on ranches, and by 38 months on farm/ranches, the farming system most similar to that in Namibia (Lorenz et al. 1986).

Although dogs placed during the program did not have particularly long life spans, their effectiveness at significantly reducing annual levels of livestock loss (Marker et al. 2005), combined with the low initial costs for farmers, means that this is an efficient and cost-effective way of reducing stock losses without resorting to predator exclusion or lethal techniques. We have no data to measure whether placing these guarding dogs had a direct impact on reducing predator removals on the farms and ranches concerned, but previous research has shown strong links between levels of stock loss and levels of predator removal (Ogada et al. 2003; Shivik et al. 2003). It seems likely, therefore, that reducing levels of stock loss could have important conservation implications in this area, where depredating carnivores such as cheetahs are threatened, particularly by the actions of local ranchers (Marker et al. 2003). 


\section{MANAGEMENT IMPLICATIONS}

An effective method of reducing stock losses must be both efficient and cost-effective, and farmers will only use these techniques if there is a clear economic benefit in doing so. A working lifespan of 4.3 years, combined with the low initial cost because of donation of the dogs by the Cheetah Conservation Fund and the resultant decline in livestock losses, means that guarding dogs placed on Namibian ranches are likely to be substantial economic assets for recipient farmers. However, almost half of the dogs placed were removed during the study period, and this proportion must be reduced in order to make this management technique as efficient and cost-effective as possible for farmers. The high level of culling and accidental deaths could be prevented with more farmer education and better care of the dogs, and with such changes the use of guarding dogs seems likely to be a very useful and economically viable method of reducing stock losses in a wide variety of situations.

\section{ACKNOWLEDGMENTS}

The authors would like to thank both the Namibian farmers and the Namibian government, particularly the Ministry of Environment and Tourism, without whose support this research would not have been possible. We are very grateful to Dr Ray Coppinger from Hampshire College in Amherst, Massachusetts, for his early interest and support of the project and for bringing the original Anatolian Shepherds to Namibia, and to the Birinci kennels for the donation of the original dogs. We are also grateful to the team of Cheetah Conservation Fund staff and volunteers and the 2 anonymous reviewers.

\section{LITERATURE CITED}

Allen, L. R., and E. C. Sparkes. 2001. The effect of dingo control on sheep and beef cattle in Queensland. Journal of Applied Ecology 38:76-87.

BergeR, J. 1999. Anthropogenic extinction of top carnivores and interspecific animal behaviour: implications of the rapid decoupling of a web involving wolves, bears, moose and ravens. Proceedings of the Royal Society of London, Series B 266:2261-2267.

Bruggers, R. A., and M. E. Zaccagnini. 1994. Vertebrate pest problems related to agricultural production and applied research in Argentina. Vilda Silvestre Neotropica 3:71-83.

ButLeR, J. R. A. 2000. The economic costs of wildlife predation on livestock in Gokwe communal land, Zimbabwe. African Journal of Ecology 38:23.

Coppinger, R., And L. Coppinger. 1980. Livestock-guarding dogs: An Old World solution to an age-old problem. Country Journal 7:68-77.

GreEN, J. S., AND R. A. WoodrufF. 1990. Livestock guarding dogs: protecting sheep from predators. U.S. Department of Agriculture. Agriculture Information Bulletin No 588, p. 32.

Green, J. S., R. A. Woodruff, and T. A. Tueller. 1984. Livestock-guarding dogs for predator control: costs, benefits and practicality. Wildlife Society Bulletin 12(1):44-50.

Joubert, E., and P. K. N. Mostert. 1975. Distribution patterns and status of some mammals in South West Africa. Madoqua 9.

LANDRY, J.-M. 2001. The guard dog: protecting livestock and large carnivores. In: R. Field, R. J. Warren, H. Okarma, and P. R. Sievert. [eds.]. Wildlife, land, and people: Priorities for the 21 st century. Bethesda, MD: The Wildlife Society. $p$. 209-212.

LinneLL, J. D. C., AND 0. StRAnd. 2000. Interference interactions, co-existence and conservation of mammalian carnivores. Diversity \& Distributions 6:169.

LORENZ, J. R., AND L. COPPInGER. 1986. Raising and training a livestock-guarding dog. Corvallis, OR: Oregon State University Extension. Circular 1238. $31 \mathrm{p}$.

Lorenz, J. R., R. P. Coppinger, and M. R. Sutherland. 1986. Causes and economic effects of mortality in livestock guarding dogs. Journal of Range Management 39:293-295.

Marker, L. L., A. J. Dickman, and D. W. Macdonald. 2005. Perceived effectiveness of livestock-guarding dogs placed on Namibian farms. Rangeland Ecology \& Management 58:329-336.

Marker, L., A. J. Dickman, M. G. L. Mills, and D. W. Macdonald. 2003. Aspects of the management of cheetahs trapped on Namibian farmlands. Biological Conservation 114(3):401-412.

Mazzolli, M., M. E. Graipel, and N. Dunstone. 2002. Mountain lion depredation in southern Brazil. Biological Conservation 105:43-51.

MishRA, C. 1997. Livestock depredation by large carnivores in the Indian transHimalaya: conflict perceptions and conservation prospects. Environmental Conservation 24:338-343.

Ogada, M. 0., R. Woodroffe, N. 0. Oguge, and L. G. Frank. 2003. Limiting depredation by African carnivores: the role of livestock husbandry. Conservation Biology 17:1521-1530.

OLI, M. K., I. R. TayloR, and M. E. Rogers. 1994. Snow leopard Panthera uncia predation of livestock: an assessment of local perceptions in the Annapurna conservation area, Nepal. Biological Conservation 68:63-68.

RASMUSSEN, G. S. A. 1999. Livestock predation by the painted hunting dog Lycaon pictus in a cattle ranching region of Zimbabwe: a case study. Biological Conservation 88:133-139.

Shivik, J. A., A. Treves, and P. Callahan. 2003. Nonlethal techniques for managing predation: primary and secondary repellents. Conservation Biology 17: 1531-1537.

Sims, D. E., And O. Dawydiak. 1990. Livestock protection dogs: Selection, care and training. Centreville, AL: OTR Publications. $128 \mathrm{p}$.

Terborgh, J., L. Lopez, P. Nunez, M. Rao, G. Shahabudin, G. Orihuela, M. Riveros, R. Ascanio, G. H. Adler, T. D. Lambert, and L. Balbas. 2002. Ecological meltdown in predator-free forest fragments. Science 294:1923.

Treves, A., and U. Karanth. 2003. Human-carnivore conflict and perspectives on carnivore management worldwide. Conservation Biology 17:1491-1499.

Woodroffe, R. 2001. Strategies for carnivore conservation: Lessons from contemporary extinctions. In: J. L. Gittleman, R. K. Wayne, D. W. Macdonald, and S. M. Funk [eds.]. Carnivore conservation. Cambridge, UK: Cambridge University Press. p. 61-92.

Yom-Tov, Y., S. Ashkenazi, And O. Viner. 1995. Cattle predation by the golden jackal Canis aureus in the Golan Heights, Israel. Biological Conservation 73:19-22. 